\title{
Polymer Composites for Bone Reconstruction
}

\author{
Mervi Puska, Allan J. Aho and Pekka Vallittu \\ University of Turku, Turku Clinical Biomaterials Centre - TCBC
}

Finland

\section{Introduction}

The need for reconstructive surgery of bones is continuously increasing along with the ageing of the population as well as the increase of traumatologic injuries. In the United States, the number of bone grafts was 350,000 in 2001. Nowadays, over 500,000 bone graft procedures are performed annually, and approximately 2.2 million worldwide (Giannoudis et al., 2005). The estimated cost of these procedures approaches US $\$ 2.5$ billion per year. Hence, the considerable demand for these replacement procedures cannot be met solely by using donor material. Therefore, superior synthetic orthopaedic materials and techniques should be available on the market for clinical practice. Adjustable porosity, bioactivity, identical biomechanics, as well as all the other tissue-friendly properties to bone are central for achieving a durable, bonding-like, interface between the synthetic material and bone (Aho et al., 2004). Actually, modern material technology would have all the know-how for preparing excellent synthetic orthopaedic materials. Autografts are still regarded as optimal reconstruction material, because of the lack of good enough synthetic materials. However, in orthopaedics, the demands for synthetic materials could be fulfilled by using composite structures. In fact, it is possible to mimic better the structures of living materials, like bone, cartilage or teeth using composite structures. Therefore, there is still a constant need to search for better synthetic bone substitute materials for tissue engineering (Chung et al., 2007).

\section{Clinical background}

Typically, the synthetic bone substitute materials have traditionally been in the form of blocks, granules, mass, or gel. Although these kinds of materials are commercially available under several different trademarks, only a few defects are so far repaired using synthetic bone substitutes in clinical practice, in ca. 10\% of cases (Stevens et al., 2008). Table 1 shows different types of materials that are employed as bone substitutes. Basically, only metallic materials, of the commercially available synthetic biomaterials, are mechanically good enough to reconstruct large cortical bone defects. Of donor materials, autograft is bone that is removed from the patient's own body, whereas allograft is bone that is removed from the same species (i.e. other humans). In addition, xenograft is also of biological origin; it is extracted from the inorganic phase of mammal bone but of some other species, typically e.g. that of neat. In fact, the use of autograft is drastically limited, because of the lack of availability and donor site morbidity limits. On the other hand, the risk of infection 
transmission is a major concern that restricts the use of allografts and xenografts (Kappe et al., 2010; Tadic \& Epple, 2004).

In the bone reconstructions, polymeric materials, such as, e.g. polymethylmethacrylate (PMMA) or polyethylene (UHMWPE), have been employed as PMMA-based bone cements or as acetabular cups of hip prostheses, for several years. In fact, their use will further increase in tissue engineering (Boyer et al., 2009; Gasser, 2000; Wang, 2003). Therefore, synthetic polymers used as biomaterials have sometimes even been called biopolymers. However, the concept of biopolymers has been traditionally reserved for the polymers, i.e. macromolecules that living organisms produce, e.g. cellulose, proteins, chitin, RNA and DNA. Therefore, biopolymers are also polymers that are employed in biomedical applications (Fukushima et al., 2011; Vieira et al., 2011).

\begin{tabular}{|l|l|}
\hline ALLOGRAFT & AUTOGRAFT \\
\hline $\begin{array}{l}\text { Infection risk } \\
\text { Eanagement of bone bank is difficult }\end{array}$ & $\begin{array}{l}\text { Lack of availability } \\
\text { Damage to healthy bone tissues } \\
\text { Secondary surgical procedure needed }\end{array}$ \\
\hline METALLIC MATERIALS & POLYMER-BASED MATERIALS \\
\hline $\begin{array}{l}\text { Metal-bone interface mechanical } \\
\text { Loosening risk }\end{array}$ & $\begin{array}{l}\text { Residual toxic monomers, e.g. } \\
\text { Risk of exothermic effects, hypotonia, or } \\
\text { heart and lung complications } \\
\text { Release of nanoparticles }\end{array}$ \\
$\begin{array}{l}\text { BIOCERAMICS AND BIOACTIVE } \\
\text { GLASSES }\end{array}$ & Risk of wear debris \\
\hline $\begin{array}{l}\text { Brittleness } \\
\text { Stress shielding } \\
\text { High modulus of elasticity }\end{array}$ & OTHER, e.g. Xenografts \\
\hline
\end{tabular}

Table 1. The main material categories to reconstruct bone, and some of their typical disadvantages

\section{Methods to study materials for bone reconstruction}

Biomaterial research is focused on the design and development of synthetic materials for surgery. Therefore, a multidisciplinary research environment, i.e. combining medical sciences and biotechnology with chemistry, biology and physics, is needed. More precisely, the required testing categories include (1) chemical analysis, (2) biomechanical engineering, (3) biological testing (biomimetic biomineralization, cell culture and in vivo studies), and (4) advanced imaging technology. In fact, in order to develop synthetic materials for bone reconstruction, a well-equipped biomaterial research laboratory has a wide range of instruments, such as microcomputed tomography (micro-CT), nuclear magnetic resonance (NMR) and fourier transform infrared spectroscopy (FTIR) spectrometers, and thermoanalytical techniques: e.g. differential scanning calorimeter (DSC) or thermomechanical analyzer (TMA), high performance liquid chromatography (HPLC), scanning electron microscope (SEM) or transmission electron microscope (TEM), and material testing machines (e.g. Lloyd LRX or Instron equipments). In addition, facilities for the synthesis of 
organic molecules and biopolymers are needed. To carry out biological testing, the cell culture and histological laboratory, standard stainings and molecular biology techniques should be available, as well as several light microscopes and a computer-based histomorphometric analysis system (e.g. Aho et al., 2004; Meretoja et al., 2006; Puska et al., 2003; Silva Nykänen et al., 2011).

\section{Composites for bone reconstruction}

Modern synthetic chemistry has reached the point where it is possible to prepare molecules in almost any structure. Methods are available to produce a wide variety of useful materials, such as bioactive or chiral self-assembled polymer structures (Cui et al., 2010; Wang, 2008). For example, phosphorus-containing biopolymers have been synthesized and developed as polymeric candidates for potential tissue engineering applications (e.g. poly[bis(methacrylate)]phosphazene, PMAP) (Silva Nykänen et al., 2011). In the polymeric structure, the presence of phosphorus may improve the biocompatibility of polymers by enhancing their tissue contact. Actually, phosphorus is an essential element in all living systems, e.g. as a key part of the phosphodiester bonds in DNA and RNA.

In addition, in the form of thermosets and thermoplastics, both biostable and biodegradable polymers (e.g. polycaprolactone, PCL and PMMA) have been studied, largely for tissue engineering (Aho et al., 2004; Middleton \& Tipton, 2000; Morita et al., 1998; Puska et al., 2003; Wang, 2003). Structurally, the form of these polymers can be linear, cross-linked or interpenetrated polymer networks (IPNs). IPNs are three-dimensional physically or chemically cross-linked polymeric materials that include two independent networks without any covalent bonds between them (Feng et al., 2004; Sperling 1994). Polymer composites are combinations of two or more components, usually containing an inorganic phase and a polymer phase that are essentially insoluble in each other (Gasser, 2000). Polymers have typically lower modulus and deformation resistance than the inorganic phase. Thus, attempts are made to adjust the mechanical properties of polymeric materials to approximate those of bone, using a composite structure. In fact, the matrix polymercontaining filling components result in a complicated interaction between the properties of every constituent phase, i.e. (a) the matrix, (b) filling components, and (c) the interfacial region between the filling components and the matrix polymer (Wang, 2003).

\subsection{Chemistry of PMMA-based bone cements}

For over 40 years, the best known polymeric material or "biopolymer" has been PMMAbased bone cement. Typically, PMMA-based bone cements are employed in many orthopaedic operations, e.g. in total joint replacement surgery, substitutes in vertebroplasty/kyphoplasty, or as filling material in trauma surgery (Boyd et al., 2008; Lewis, 2009). Commercially available bone cements are made of (a) a powder component consisting of PMMA polymer or related block copolymers and (b) a liquid component made of methylmethacrylate (MMA) or related monomer liquids. Just before the clinical procedure, bone cement is fabricated by combining the powder and the liquid component together. In fact, the monomer phase dissolves the powder component and, thereafter, it autopolymerizes within $10-15$ min, resulting first in a mouldable viscous dough after 3-7 min, and then a very dense cured PMMA-based bone cement. More precisely, the powder component contains PMMA or related block copolymer beads (diameter $50 \mu \mathrm{m}$ ), an initiator, and radio-opaque substances. The liquid is methylmethacrylate (MMA) monomer or related 
methacrylic monomers that polymerise in the presence of the initiator. Structurally, PMMAbased bone cements are formed of typical linear polymers. However, PMMA-based bone cement can also be modified in the form of a semi-IPN structure by adding small amounts of cross-linking monomers (e.g. 2-30 wt\% of ethylene glycol dimethacrylate, egdma) to the liquid phase (Lewis, 2009; Puska et al., 2003, 2004). In future tissue reconstruction applications, the acrylic polymer matrix will most probably also be modified using dendritic macromonomers.

In joint replacement surgery, the main function of PMMA-based cement is to transfer body weight in order to increase the load-bearing and fixation capacity of the reconstruction area. On the other hand, PMMA-based cement is morphologically very dense, thus not allowing bone ingrowth. In addition, the exothermal polymerization of MMA in vivo might cause a risk of thermal and chemical necrosis of bone. However, in most cases, PMMA-based cements have been successfully utilized in orthopaedic surgery for many decades (Lewis 2009; Puska et al., 2003). Therefore, interest has arisen in developing more biocompatible PMMA-based cements. In fact, their weakest link is the dense non-bioactive cement-bone interface that is a barrier to direct fracture healing. Basically, it is possible to make the properties of PMMA-based bone cements more tissue-friendly, as an example of a functional active composite structure that is porous and bioactive. The porosity and bioactivity are created by filling components in both powder and liquid components, thus slightly changing the content.

In terms of bioactivity, PMMA-based cements are combined with inorganic substances, i.e. bioactive glasses, hydroxyapatite. In the literature, a number of bioactive PMMA cements are presented. Bioactive bone cements are normally successfully obtained when the PMMA matrix contains an appropriate concentration of bioactive ceramics. For example, Shinzato et al. have reported that bioactive PMMA cements containing bioactive substances have significantly higher bone-bonding strength than plain PMMA cement (Shinzato et al., 2001). However, the presence of fairy large concentrations of ceramics in PMMA can disfavour the mechanical properties. Especially if adhesion between the PMMA matrix and the particles of ceramics is missing, particles often behave like voids as crack nucleation (Abboud et al., 2000).

\subsection{Bifunctional acrylic resins as matrix components}

Bifunctional acrylic resins contain monomers with two active bonding positions. Originally, they were developed for dental applications (Schweikl et al., 2006), but nowadays these monomers have also been investigated for orthopaedic surgery. The best known bifunctional methacrylates are bisphenol-A-glycidyldimethacrylate (BisGMA) and triethylene glycol dimethacrylate (TEGDMA), Fig. 1. BisGMA-based bone cements are developed to reduce the problems encountered with bioactive PMMA cements (Boyd et al., 2008; Smit et al., 2008). Actually, highly cross-linked polymers, such as the BisGMA-based, are the only polymers that are strong enough (e.g. compression strength: $>100 \mathrm{MPa}$ ) to withstand the different types of stresses of cortical bone (Gheduzzi et al., 2006). Especially Japanese researchers have been very active in studying BisGMA-based cements (Kobayashi et al., 1999).

One commercially available highly cross-linked biostable cement is Cortoss ${ }^{\circledR}$ (Orthovita, Malvern, USA) that comprises three main resins: BisGMA and ethoxylated bisphenol A dimethacrylate (BisEMA) and TEGDMA as a viscosity modifier. In addition, Cortoss ${ }^{\circledR}$ contains reinforcing particles of silica, barium boro-aluminosilicate glass and combeite glass 
<smiles>C=C(C)C(=O)OCC(O)COc1ccc(C(C)(C)c2ccc(OCC(O)COC(=O)C(=C)C)cc2)cc1</smiles>

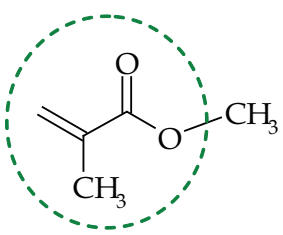

(a)

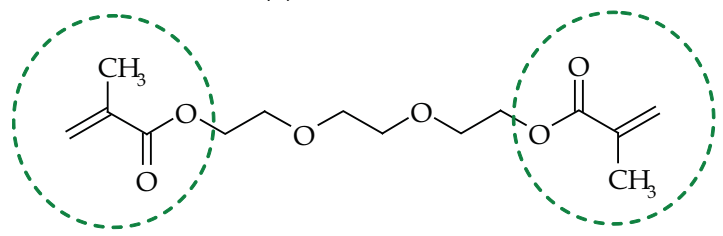

(c)

(b)<smiles>C=C(C)C(=O)OCCC[Si](OC)(OC)OC</smiles>

(d)

Fig. 1. The molecule structures of compounds containing methacrylate group: (a) bisphenolA-glycidyldimethacrylate, BisGMA, (b) methylmethacrylate, MMA, (c) triethylene glycol dimethacrylate, TEGDMA, and (d) methacryloyloxypropyltrimethoxysilane, MPS. The circles show active bonding positions that are able to react with other monomers, i.e. necessary for the curing/hardening of acrylic bone cement

ceramic, as well as a silane coupling agent (Boyd et al., 2008; Gheduzzi et al., 2006; Smit et al., 2008). The setting time of Cortoss ${ }^{\circledR}$ cement is reported to be between 4 and 8 min, thus very suitable for bone reconstruction. The main drawbacks of Cortoss ${ }^{\circledR}$ are its missing porosity and, in some cases, the biodegradation of matrix polymer. In addition, the cements that are mechanically very strong may introduce stress shielding that is observed if the material exhibits much greater stiffness compared to the modulus of cortical bone. Another potential problem occurs if BisGMA-based cements are employed in vertoplasty. The extreme strengthening of one vertebra may potentially cause a fracture in the neighbouring osteoporotic vertebra. In fact, these acrylic monomers are also identified as being harmful in mammalian cells. Some of these substances can induce, e.g. gene mutations, probably because of the covalent binding to DNA via Michael addition (Schweikl et al., 2006).

\subsection{Biodegradable polymers as matrix polymers}

Since the mid-1990s, biodegradable polymer composites appear to have been studied for the applications of tissue engineering (Aho et al., 2004; Meretoja et al., 2006; Middleton \& Tipton, 2000; Törmälä, 1992; Wang, 2003). In these, the typical matrix polymers are polylactide (PLA), polycaprolactone (PCL), polypropylenefumarate (PPF) or any of their copolymers. Basically, biodegradable polymer composites are prepared by mixing bioactive compounds in a certain fragment volume with melt/dissolved polymer (Rezwana et al 2006, Wang 2003). Typically, matrix polymers in these biocomposites are delivered as viscous liquids or mouldable pastes. The intermediate phase of the biodegradable polymer composites is a soft mouldable mass that hardens relatively fast in $20 \mathrm{~s}-1 \mathrm{~min}$. The compression strength of these biodegradable composites is rather low, between 10 and $50 \mathrm{MPa}$. However, the biodegradable composites containing bioactive compounds are osteoconductive and easy to handle. Therefore, they are very suitable as bone grafting substitutes for small cancellous bone or cartilage defects (Aho et al., 2004; Meretoja et al., 2006; Wang, 2003). 
Some years ago, Aho et al. reported one injectable biodegradable composite that contains particles of bioactive glass embedded in poly(caprolactone-co-D,L-lactide) matrix. The glass particles in matrix polymer resulted in osteoconductivity (Aho et al., 2004). In addition, Leeuwenburgh et al. have developed a nanoceramic $(\mathrm{CaP})$ polymer composite consisting of oligo(poly(ethylene glycol)fumarate) as matrix (Leeuwenburgh et al., 2007). Kim et al. have investigated an injectable PPF that is porous after injection. The porous structure is created in situ by $\mathrm{CO}_{2}$ bubbles that are generated in a reaction of bicarbonate salt and weak acid (Kim et al., 2009). Łukaszczyk et al. have introduced a poly(3-allyloxy-1,2-propylene)succinate-based biodegradable bone cement that would have a tendency to set in situ in vivo by cross-linking poly(3-allyloxy-1,2-propylene)succinate (PSAGE) with MMA and methacrylic anhydride (Lukaszczyk et al., 2007). In fact, injectable PPF and methacrylated polyanhydrides have aroused much interest; one reason is their in situ curing capacity.

\section{Biomechanics of composites for bone reconstruction}

In terms of filling particles, the properties of matrix polymers, such as stiffness, thermal expansion, creep resistance or fracture toughness, can be changed. If particles are incorporated in polymers, it makes the final material stiffer or harder. On the other hand, the tensile strength decreases with an increasing amount of inorganic particles. Therefore, it is important to know the type and shape of the filling particles to be able to make the right choice. In fact, the shape of the component, e.g. particles vs. fibres, depends on the application to which the load-bearing forces are directed (Garoushi et al., 2006; Puska et al., 2004; Wang, 2003).

\subsection{Reinforcing components}

The properties of composites are dependent on the type, volume fraction and orientation of the filling substance. In the case of isotropic 3D reinforcing, it can be obtained using spheres, granules or short fibres (Wang 2003). Table 2 shows some typical categories of osteogenetic composites for bone reconstruction. In terms of fibre-reinforced composites (FRCs), reinforcing fibres are employed in two forms: (a) continuous unidirectional or (b) chopped. The other main parameters affecting mechanical properties of FRC include: (1) the exact composition of fibres and polymer matrix, (2) the orientation and quantity of fibres, (3) the adhesion between fibres and polymer matrix, and (4) the impregnation of the fibres by the resin matrix. Moreover, the fibre length also significantly influences the mechanical properties (Behr et al., 2000; Thomason, 2007). In fact, the reinforcing effect of fibres can be predicted using the so-called Krenchel's factor. In the Krenchel's analysis, the orientation of the fibres and the applied load depend on each other. Continuous unidirectional fibres give the highest mechanical properties, but only anisotropically, matching the direction of the fibres (Krenchel, 1963). In tissue engineering, the reinforcing fibres of composites can be made of E-glass, bioactive glass, polyethylene, the family of aromatic amides (i.e. aramid), carbon, graphite, titanium, or fibres of natural origin.

\subsection{Interfacial aspects}

To understand the reinforcing phenomenon of polymer composites, it is very important to understand the adhesion between the matrix polymer and the reinforcing substances. It requires a lot of information to understand, e.g. how materials interact with each other, what kinds of coupling systems there are, the interface, and the failure mechanism. Failures 
often occur within the polymer or at the interface. To be precise, the surface of fillers can be modified either using (1) surface treatment or (2) chemical grafting. In fact, the surface roughness also has a significant effect on wettability by monomers or coupling agents. Using some kind of chemical surface treatment, e.g. using MPS-silane (Fig.1), a covalent bonding can be obtained between the polymer matrix and inorganic fillers at molecular level (Fig. 2) (Vallittu, 1995, 1998; Puska et al., 2009b).

\begin{tabular}{|l|l|l|}
\hline Type of polymer composite & Compression strength & Advantages \\
\hline $\begin{array}{l}\text { Biodegradable matrix polymer with } \\
\text { bioactive glasses or ceramics, Refs1 }\end{array}$ & $\begin{array}{l}\text { Low degree, } \\
\text { weak } \sim 10-50 \mathrm{MPa}\end{array}$ & $\begin{array}{l}\text { Osteogenic and } \\
\text { bone ongrowth }\end{array}$ \\
\hline $\begin{array}{l}\text { Biostable matrix polymer with } \\
\text { calcium ceramics, Ref2 }\end{array}$ & $\begin{array}{l}\text { Moderate } \\
\text { strength } \sim 80 \mathrm{MPa}\end{array}$ & $\begin{array}{l}\text { Slightly porous, osteogenic } \\
\text { and bone on- and ingrowth }\end{array}$ \\
\hline $\begin{array}{l}\text { Modified PMMA-based bone } \\
\text { cement, Ref3 }\end{array}$ & $\begin{array}{l}\text { Moderate } \\
\text { strength } \sim 70 \mathrm{MPa}\end{array}$ & $\begin{array}{l}\text { Interconnected porosity, } \\
\text { osteogenic and bone on- } \\
\text { and in-growth }\end{array}$ \\
\hline $\begin{array}{l}\text { Fibre-reinforced and highly } \\
\text { crosslinked acrylic polymer, Ref4 }\end{array}$ & $\begin{array}{l}\text { High degree, } \\
\text { strength adjustable } \\
>150 \mathrm{MPa}\end{array}$ & $\begin{array}{l}\text { Non-porous, optimal strength } \\
\text { for cortical bone, tailor-made } \\
\text { elasticity, osteogenic }\end{array}$ \\
\hline
\end{tabular}

Refs1: Aho et al., 2004; Rezwana et al., 2006; Wang, 2003;

Ref2: Puska et al., 2009a; Ref3: Puska et al., 2004; Ref4: Garoushi et al., 2006

Table 2. As bone substitutes, the osteogenic composites grouped according to their composition and biomechanics

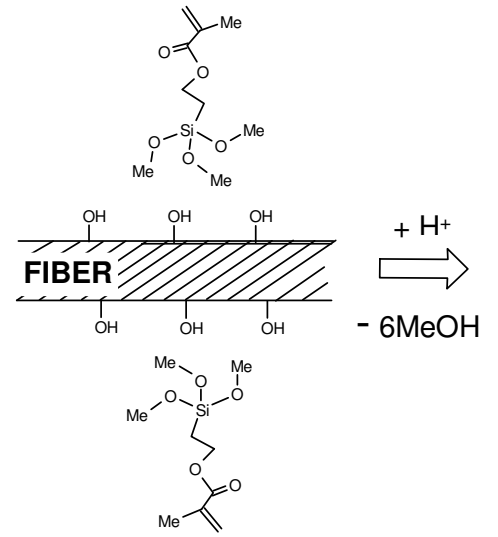

(a)

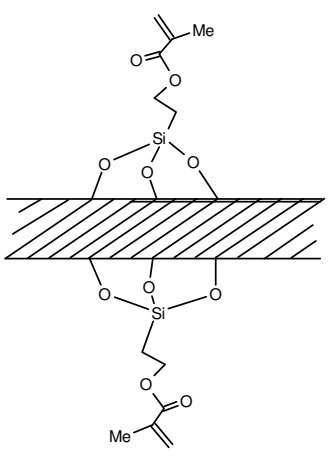

(b)

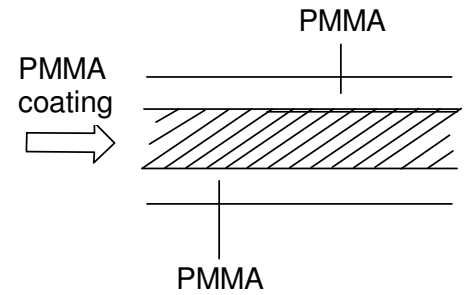

(c)

Fig. 2. Simplified presentation of glass fibre pre-impregnation with PMMA; these thin PMMA layers can be covalently bonded to the glass surface. (a) A plain tiny glass fibre strand and MPS (b) The formation of silanized layer (siloxane layer) (c) The deposition of PMMA layer 


\section{Osteoconductivity and porosity of synthetic biomaterials}

Osteoconduction is a characteristic of bone reconstructive materials that favours the spread of osteogenetic cells, i.e. osteoblasts and osteocytes, on the surface of the material. Bioactive materials are designed to induce a specific biological activity (Einhorn, 1995; Hench \& Wilson, 1984). In fact, the bioactive properties of composites can be altered by embedding the biologically active substances, such as drugs, bisphosphonates, antimicrobial agents, proteins, growth factors, enzymes and DNA into either pore-generating filler or into reinforcing components. In the case of tissue engineering, the matrix polymer could also imply bioactivity or it could contain biologically active components. In this context, bioactivity is surface reactivity that has the ability to bond with both bone and subcutaneous tissue. Basically, bioactive materials have been shown to form a direct connection to living bone through a Ca-P-rich layer. The main categories of bioactive compounds that are utilized as filling components are: (a) bioactive glasses (BAG) or apatite wollastonite glass ceramics (AW-GC), (b) calcium phosphates, and (c) calcium sulphates. Bioactive bone substitutes are normally successfully obtained when the matrix polymer contains appropriate concentrations of bioactive fillers, often more than $50 \mathrm{wt} \%$. For example, bioactive PMMA-based bone cements containing AW-GC or BAG have significantly higher bone-bonding strength than plain PMMA cement (Kenny \& Buggy, 2003).

\subsection{Bioactive glasses}

The most important feature for producing bioactive glasses is based on the specific composition of the glass, where the amount of oxides is: $\mathrm{SiO}_{2}<60 \mathrm{wt} \%$, a high $\mathrm{Na}_{2} \mathrm{O}$ and $\mathrm{CaO}$ content, and a high $\mathrm{CaO} / \mathrm{P}_{2} \mathrm{O}_{5}$ ratio (Gomez-Vega et al., 2000; Zhang et al., 2010; Hench \& West, 1996). Bioactive glasses can be produced in various shapes, e.g. as granules, spheres or in fibre form. In the case of PMMA-based bone cements, the biostable matrix polymer can be easily incorporated using bioactive glass substances. Namely, the bioactive substances used as fillers in the composite structure of inert polymer stimulate bone ingrowth into the outermost porous structure, thus accelerating the overall healing process.

\subsection{Calcium-phosphate (CaP)-based fillers}

The family of calcium phosphates $(\mathrm{CaP})$, such as tricalcium phosphate (TCP) and hydroxyapatite (HA), are osteoconductive materials. In mammals, hydroxyapatite $\mathrm{Ca}_{10}\left(\mathrm{PO}_{4}\right)_{6}(\mathrm{OH})_{2}$, is the main mineral of hard tissues (Jarcho et al., 1976). Natural HA isolated from mammal bone has very good chemical and biological affinity to bone tissue. However, HA is nowadays prepared synthetically. In fact, natural and synthetic HA are only two compounds in the category of CaP cements (Tadic \& Epple, 2004). Other compounds are tricalcium phosphate (TCP), tetracalcium phosphate (TTCP), and calcium pyrophosphate (CPP), dicalcium phosphate anhydride (DCPA) and dicalcium phosphate dehydrate (DCPD) (Chen et al., 2009; Heini \& Berlemann, 2001). The manufacturing of CaP cements involves sintering at high temperatures with exclusion of $\mathrm{H}_{2} \mathrm{O}$.

\subsection{Calcium-sulphate-based fillers}

Calcium-sulphate $\left(\mathrm{CaSO}_{4}\right)$-based materials have been utilized in the treatment of bone cavities for many decades (Abramo et al., 2010). Some alternatives of calcium-sulphate powders set in contact with water and the solid form contains two molecules of crystal water. Compared to $\mathrm{CaP}$ cements, $\mathrm{CaSO}_{4}$-based materials imply biodegradation capacity. 
Actually, plain $\mathrm{CaSO}_{4}$-based cements disappear from the body in one year (Jung et al., 2010). Therefore, $\mathrm{CaSO}_{4}$ cements are utilized as bone graft substitute in reconstruction in the distal radius. In terms of osteconductivity, $\mathrm{CaSO}_{4}$-based materials seem to be good filling components when incorporated in inert polymer matrices (Fig. 3) (Puska et al., 2009a).

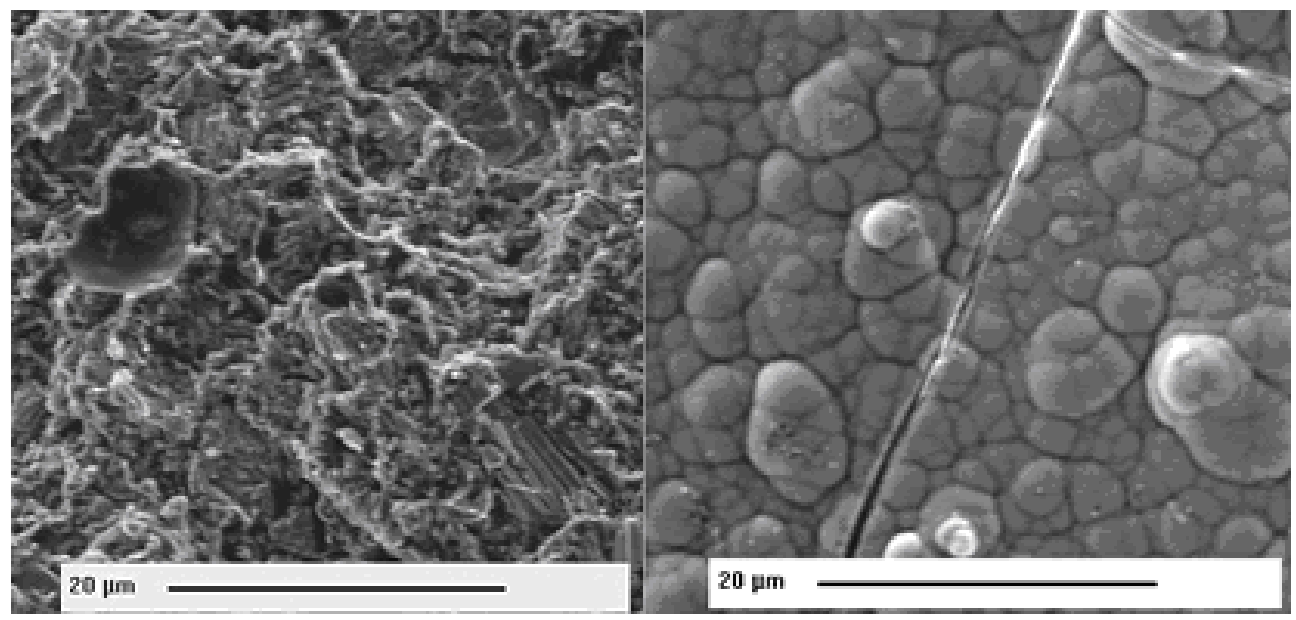

Fig. 3. On the left, structure of plain bifunctional polymer composite containing $\mathrm{CaSO}_{4}$ based materials (50wt\%) before SBF soaking. On the right, the effect of biomimetic mineralization (in SBF solution), i.e. the formation of hydroxyl apatite is significant. The length of the measuring rod is $20 \mu \mathrm{m}$ (Ref. Puska et al., 2009a)

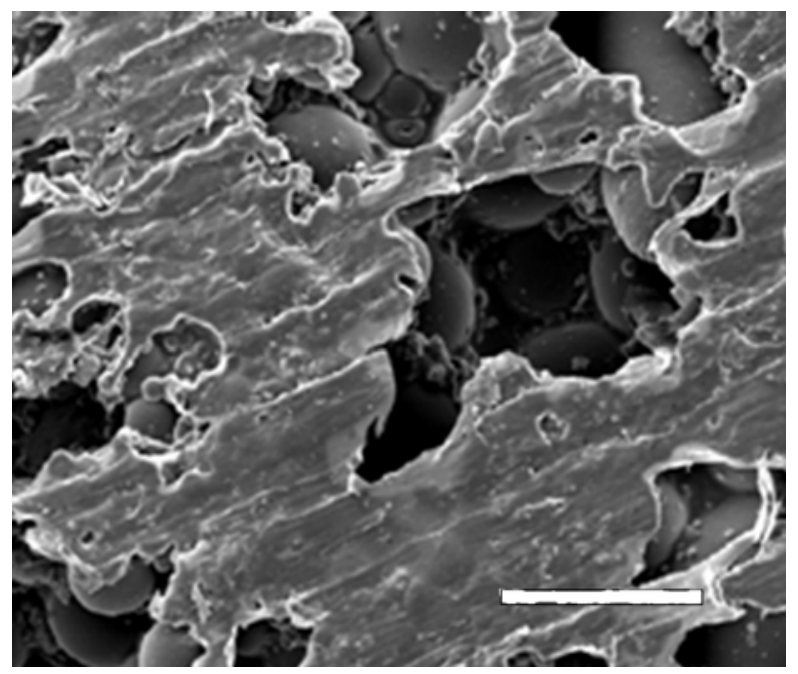

Fig. 4. The porosity of the outermost surface, i.e. in the modified PMMA-based bone cement structure after the specimen has been soaked in SBF solution. The length of the white measuring rod is $100 \mu \mathrm{m}$ 


\subsection{Porosity in biocomposites}

In biomaterials, the function of porosity is to provide a scaffold for new bone tissue ingrowth. In particular, the porosity should be continuous and interconnected, where most of the pores should be large enough $(100-500 \mu \mathrm{m})$ (Deville et al., 2006; Itälä et al., 2001). Figure 4 shows the outermost surface of modified PMMA-based bone cement. In fact, porosity formation will increase the contact surface between the living tissue and the scaffold, thus holding the implant much more tightly in place. The porous structure can be created in situ in vivo using so-called pore-generating fillers that are bioabsorbable particles embedded inside non-resorbable matrix polymer. After the implantation, these fillers will degrade in contact with body fluid. Ideally, porosity should develop fast enough after the material has been implanted into living tissue, i.e. within the first few days. However, the porosity formation also decreases the mechanical properties of the cured bone cement (Puska et al., 2003, 2004).

\section{Clinical demands}

Most biological materials (e.g. bone, dentin, or cartilage) also tend to be composites. Natural composites quite often have extremely hierarchical structures, in which particulate, porous, and fibrous structures are present. In fact, the aim of composite technology for bone reconstruction is to tailor the properties of biomaterials closer to those of repaired hard tissue (e.g. cartilage or cortical bone). Therefore, optimal reconstruction of large-size bone damages is very challenging, because bone as a biological composite is porous, thus allowing constant circulation of fluids and different types of bone cells, minerals etc. (Aho et al., 2004; Itälä et al., 2001; Meretoja et al., 2006; Puska et al., 2003). In addition, if artificial materials are implanted into bone, there is a constant risk of infections. The properties of bone vary, i.e. depending on the anatomic location in the skeleton and the bone (Fig. 5). More precisely, biological criteria for reconstruction materials are classified according to the size, form and quality of bone (Ritchie et al., 2006). In addition, cortical bone as load-bearing sites of the skeleton also has specific elastic, anisotropic and heterogeneous structural properties that differ significantly from cancellous bone. More precisely, the compression strength of cortical bone is reported to be between 100 and $200 \mathrm{MPa}$, whereas the compression strength of cancellous bone is only between 2 and $12 \mathrm{MPa}$ (Reilly \& Burstein, 1974, Lotz et al., 1991).

In the case of bone reconstruction, the choice of the best available biomaterial has to be decided from among the alternatives of the categories presented in Table 1 . Therefore, the clinician has to make the decision according to information based on the availability of materials versus the condition of the patient that depends on his/her age, physical size (height/ weight), health, and genotype, as well as the shape, size and location of the defect. After operation, when biomaterials are in very close contact with bone, the new bone formation occurs as an osteoconductive growth, i.e. osseointegration on the surface of the material (ongrowth) or into the material (ingrowth) if there is a suitable amount of porosity and bioactivity (Aho et al., 2004). In terms of osteoinduction, biomaterial also accelerates new bone formation by chemical means (e.g. bioactive glasses) (Hench \& Wilson, 1984; Hench \& West, 1996).

Sometimes, bone does not create a durable ongrowth to the biomaterial's surface, e.g. in the case of encapsulation, when a so-called foreign body reaction takes place. In order to avoid this, the employed biomaterial should have bioactivity and porosity, thus allowing a tight 
osseointegration or even bone ingrowth into the interconnected 3D porous interfaces. On the other hand, in the case of totally or partially biodegradable biomaterials, the remodelling of new bone and the degradation of biomaterial should occur simultaneously.
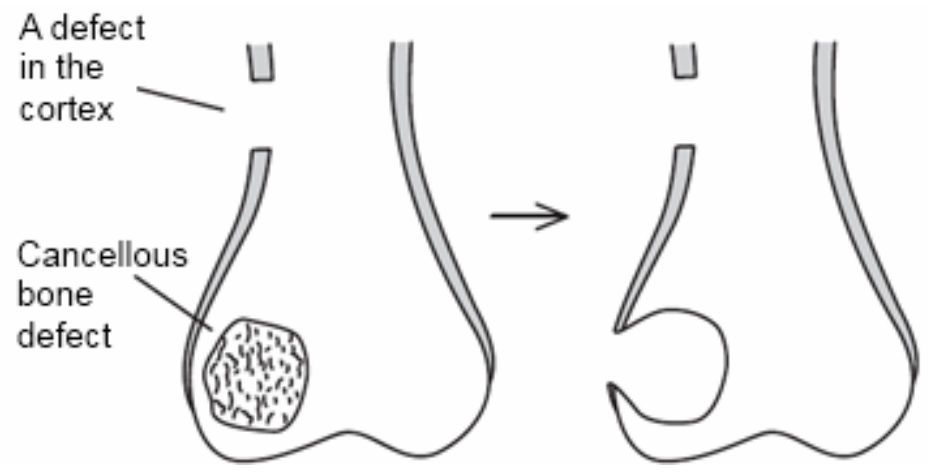

Fig. 5. Biomechanically, the highest load-bearing capacity of bone is needed on the outermost sites of bone. Therefore, if these parts of bone are reconstructed, the mechanical properties of the synthetic bone substitute should be similar to those of bone

\subsection{Biological function: Bone grafting}

Bone grafting is a surgical procedure, in which the bone defect or the missing bone is replaced with natural or artificial substitutes. More precisely, these are substitutes of natural origins (donor materials) or synthetic bone substitutes, i.e. inorganic compounds, polymeric materials, or biocomposites.

In fact, a highly sophisticated synthetic bone substitute should have:

1. porosity allowing new bone ongrowth and ingrowth,

2. bioactivity (i.e. osteoconductivity and/or osteoinductivity),

3. suitable mechanical properties (i.e. elasticity and weight-bearing capacity), and

4. physical form permitting application by injection as a paste or gel.

If these properties could be achieved, bone reconstruction surgery would most probably be more cost-effective in the long run; especially because improvement in the patients' quality of life would also be achieved.

In fact, an optimal synthetic bone substitute should be structurally and biomechanically as close to surrounding bone as possible. Typically, synthetic bone substitutes are employed in the treatment of broken bones in the vertebra, wrist or hip, often due to osteoporosis. In this disease, the progressive loss of bone tissue has made the skeleton weaker and more prone to fractures, because the amounts of collagen and calcium salts are depleted. In vertebroplasty/kyphoplasty, low viscosity bone substitutes are injected into the collapsed spinal vertebra in order to stabilize and strengthen the crushed bone (Erbe et al., 2001; Gisep et al., 2006).

As a superior composite (Fig. 6), the synthetic bone substitute would have: (1) tailor-made biomechanics, i.e. elasticity and weight-bearing capacity, (2) non-toxicity, (3) bioactivity (i.e. osteoconductivity and/or osteoinductivity), (4) porosity of ca. 20-40 vol\%, allowing new bone ongrowth and ingrowth, (5) possibility to attach/incorporate other substances (bioactive glass, growth factor, mesenchymal stem cells, etc.), and (6) physical form permitting application by injection/kneading as a paste or gel, and in some cases (7) highly 
controlled biodegradation by surface erosion mechanism, if the matrix polymer is biodegradable and remodelling of new bone is assumed to be sufficient (Aho et al., 2004).

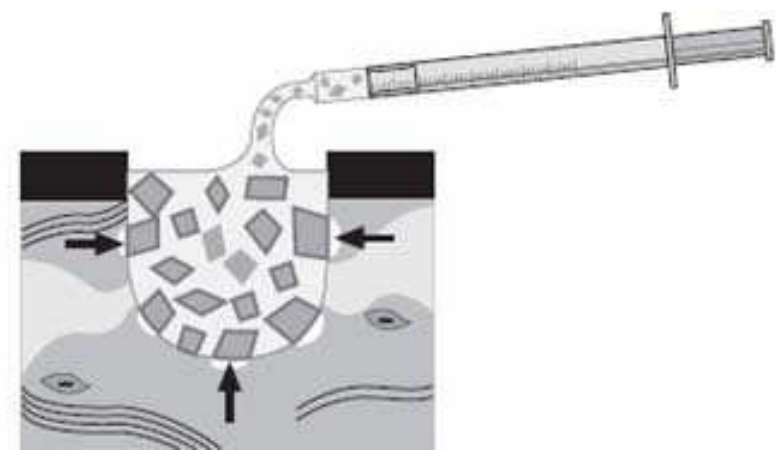

Fig. 6. In more sophisticated cases, bone defects can be reconstructed with a mouldable mass that is injected into the bone. This kind of dough-like substitute should also contain the bioactive substances and pore-generating fillers (Ref. Aho et al., 2004)

\subsection{Challenges of artificial materials for bone reconstruction of arthritic disorders}

Arthritis is a joint disorder featuring inflammation. The two most common types of arthritis are osteoarthritis and rheumatoid arthritis that usually involve various joints such as those in fingers, spine, legs or arms. Rheumatoid arthritis is an autoimmune inflammatory disease, whereas osteoarthritis is mostly related to ageing, but can also be caused by a disease. In the case of very severely damaged bone, the only treatment is joint replacement surgery. In this, a joint is amputated and replaced with a metallic prosthesis, e.g. in hips or knees (Boyer et al., 2009).

The artificial parts of the prosthesis are often cemented into place by PMMA-based bone cement (Lewis 2009). The PMMA-based bone cement layer adheres tightly to the prosthesis in the skeleton and acts as an intermediate bumper. Therefore, the patients can normally walk with their newly implanted knees or hips very soon after the operation. As medical devices, metallic implants, made of stainless steel or titanium, are most frequently used in total joint replacements. However, metals exhibits much greater stiffness compared to the elasticity of bone. In the fixation of the prosthesis, the large elasticity difference between these two materials can cause stress shielding that leads to an increase in bone porosity and atrophy. In addition, there are some other clinical problems such as the activation of periprosthetic connective tissue, macrophage activation, and bone resorbtion, as well as wear and corrosion problems (Santavirta et al., 1998, 1999). Release of nanosized particles of metal may also have undesired effects on the biology of tissues.

The main disadvantage associated with the use of traditional PMMA-based bone cement is the anchoring effect that happens only as a mechanical locking, because the surface of the polymerised bone cement is of a dense structure that does not allow the bone to grow into the cement (i.e. mechanical locking). Therefore, new bone formation is limited only to the surface between the bone cement and the bone. If the fixation is only mechanical, the micromotion between the bone and the implant interface can lead to resorbtion of bone and then the failure and the final loosening of the prosthesis (Santavirta et al., 1998, 1999). Therefore, some re-operations of total knee/hip replacement systems have been required even within four to eight years after the primary operation (Hooper et al., 2009), although all 
the prostheses should last for the rest of the patients' life. To avoid re-operations, these prosthetic implant materials should be developed to approximate more closely to the properties of bone (e.g. elasticity).

\section{Clinical applications}

A wide range of porous composites for tissue engineering has been studied. In fact, if porous scaffolds are utilized effectively in load-bearing applications, the mechanical properties of materials with porosity and void spaces should be known. In clinical applications, the tailor-made composite structure materials could be employed as follows: (1) in osteoarthrosis, (2) in the treatment of osteoporotic fractures, (3) in the controlled filling of defects, and (4) as bone grafting materials (Fig. 7).

In vertebroplasty/kyphoplasty, low viscosity cements, e.g. modified PMMA-based bone cements, could be injected into the collapsed spinal vertebra in order to stabilize and strengthen the crushed bone (Hulme et al., 2006). Actually, the optimal setting/curing time for biomaterials in vertebroplasty is still under investigation. For the application of tissue engineering, it should be possible to tailor the curing of materials. In fact, according to our studies, this is possible using a specific type of wave energy that increases the polymerization of matrix polymer. Thus, the ultimate strength of the substitute can be achieved in a couple of minutes after mixing the components. In the fixation of fractures of the radius, the better curing would also improve the quality of bone reconstruction. In arthroscopic surgery, the injection of bone substitute with controlled curing would probably allow the possibility of operating without opening the joint using a micro-invasive technique.



Fig. 7. Synthetic bone substitutes can be utilized in typical surgical defects of fractured bone. Typically, bone defects are reconstructed in the distal radius or vertebra

Bone fractures and tumour defects often locate in long bone. In the reconstruction of bone, autograft bone is assumed to be the best alternative. However, bone defects could also be reconstructed using synthetic materials that can interact with biological systems (Lindfors et al., 2009). In the case of composites, tailor-made structures could serve as an alternative for the traditional implant devices. In contact with living hard tissues, the composite structures are able to adapt according to the biological and mechanical requirements. The authors of this book chapter have developed new materials and techniques, where the composite material will meet the clinical demands including the adjustability and highly controlled setting of the material (Aho et al., 2004; Puska et al., 2003, 2004, 2009a). Figure 8 shows one example of our experimental materials for bone reconstruction. In our coming papers, these new alternatives that have properties like putty form, easy handling and good filling, but 
are also biomechanically suited to bone tissue, will be presented. In fact, it is predicted that a number of autografts will in future be replaced by the more sophisticated biomaterials. From the patient's point of view, this would be a huge improvement. Thus, the mutilation of bone and secondary operation would be avoided.
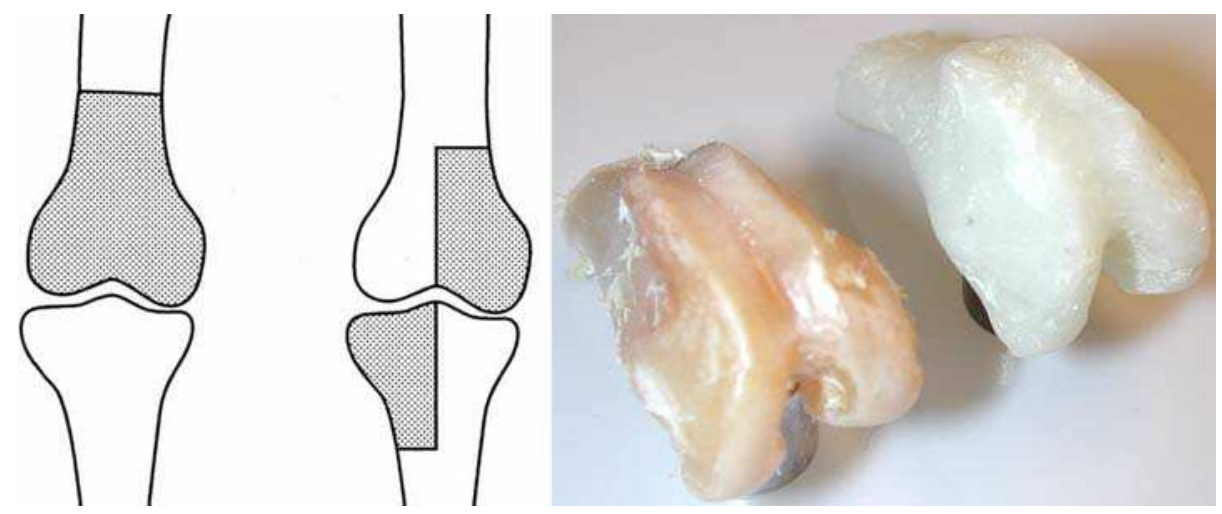

Fig. 8. Synthetic reconstruction materials can be utilized as osteoarticlular graft for bone tumour surgery. On the right, the image presents a natural rabbit knee joint and beside it an artificial joint made of bifunctional polymer composite (Aho et al., 2007)

\section{Summary}

In the biological environment, the demands of biomaterials are challenging. Typically, in the reconstruction of bone defects, clinicians use autograft bone, based on the fact that the commercially available synthetic materials are not optimal for the reconstruction of bone. Nevertheless, calcium-based compounds are generally marketed under several trade names. In fact, they are only suitable in a few fixations of bone defect, e.g. to fill the defects in cancellous bone. On the other hand, in the case of artificial joint reconstruction, the biomechanical properties of inorganic compounds or metallic materials do not respond to the demands of bone. In terms of composite structures, bone substitutes can be adjusted to be closer to the demands of bone. Thus, polymer composites mimic the structures of bone better, because they can be tailor-made to be both osteoconductive and strong enough to withstand weight-bearing. These better synthetic bone substitutes will most probably be commercially available for orthopaedic applications in the near future.

\section{Acknowledgments}

In terms of our own studies presented in this book chapter, the research has partly been funded by the Academy of Finland (grant number: 128636) and the Finnish Dental Society APOLLONIA. Prof. Antti Yli-Urpo is acknowledged for his encouragement in the topic of functionally active bone cements and substitutes.

\section{References}

Abboud, M.; Casaubieilh, L.; Morvan, F.; Fontanille, M.; Duguet, E. (2000). PMMA-based composite materials with reactive ceramic fillers: IV. Radiopacifying particles 
embedded in PMMA beads for acrylic bone cements. Journal of Biomedical Materials Research, Vol.53, No.6, pp. 728-736, ISSN 1552-4973

Abramo, A.; Geijer, M.; Kopylov, P.; Tägil, M. (2010). Osteotomy of distal radius fracture malunion using a fast remodeling bone substitute consisting of calcium sulphate and calcium phosphate. Journal of Biomedical Materials Research Part B: Applied Biomaterials, Vol.92B, No.1, (January 2010), pp. 281-286, ISSN 1552-4973

Aho, A.J.; Tirri, T.; Kukkonen, J.; Strandberg, N.; Rich, J.; Seppälä, J.; Yli-Urpo, A. (2004). Injectable bioactive glass/biodegradable polymer composite for bone and cartilage reconstruction: concept and experimental outcome with thermoplastic composites of poly(epsilon-caprolactone-co-D,L-lactide) and bioactive glass S53P4. Journal of Materials Science: Materials in Medicine, Vol.15, No.10, pp. 1165-1173, ISSN 0957-4530

Aho, A.J.; Puska, M.; Vallittu, P. (2007) A New Calcium Salt-Resin Composite for Bone Crafting. 16th International Congress of the European Association of Tissue Banks (EATB 2007), p. 39, Budapest, Hungary, October 17-20, 2007

Behr, M.; Rosentritt, M.; Lang, R.; Handel, G. (2000). Flexural properties of fiber reinforced composite using a vacuum/pressure or a manual adaptation manufacturing process. Journal of Dental Research, Vol.28, No.7, pp. 509-514. ISSN 0022-0345

Boyd, D.; Towler, M.R.; Wren, A.; Clarkin, O.M. (2008). Comparison of an experimental bone cement with surgical Simplex ${ }^{\circledR} \mathrm{P}$, Spineplex ${ }^{\circledR}$ and Cortoss ${ }^{\circledR}$, Journal of Materials Science: Materials in Medicine, Vol. 19, No. 4, pp. 1745-1752, ISSN 0957-4530

Boyer, P.; Lazennec, J.-Y.; Poupon, J.; Rousseau, M.-A.; Ravaud, P.; Catonné, Y. (2009). Clinical and biological assessment of cemented titanium femoral stems: an 11-year experience. International Orthopaedics, Vol.33, No.5, pp. 1209-1215, ISSN 0341-2695

Chen, W.C.; Ju, C.P.; Tien, Y.C.; Lin, J.H. (2009). In vivo testing of nanoparticle-treated TTCP/DCPA-based ceramic surfaces. Acta Biomaterialia, Vol.5, No.5, pp. 1767-1774, ISSN 1742-7061

Chung, U.; Itaka, K.; Nishiyama, N.; Takato, T.; Kawaguchi, H.; Nakamura, K.; Kataoka, K. (2007). Scaffolds for Skeletal Regeneration. NanoBioTechnology, Vol.3, No.2, pp. 104106, ISSN 1550-7033

Cui, H.; Pashuck, E.T.; Velichko, Y.S; Weigand, S.J; Cheetham, A.; Newcomb, C. J.; Stupp, S. I. (2010) Spontaneous and X-ray-Triggered Crystallization at Long Range in SelfAssembling Filament Networks. Science, Vol.327, No.5965, pp. 555-559, ISSN 0036-8075

Deville, S.; Saiz, E.; Tomsia, A.P. (2006) Freeze casting of hydroxyapatite scaffolds for bone tissue engineering. Biomaterials, Vol.27, No.32, pp. 5480-5489, ISSN 0142-9612

Einhorn, T.A. (1995). Enhancement of fracture-healing. Journal of Bone and Joint Surgery American Volume, Vol.77, No.6, pp. 940-956, ISSN 1535-1386

Erbe, E.; Clineff, T.; Gualtieri, G. (2001) Comparison of a new bisphenol-a-glycidyl dimethacrylate-based cortical bone void filler with polymethyl methacrylate. European Spine Journal, Vol.10, Suppl, pp. S147-S152, ISSN 0940-6719

Feng, X.Q.; Tian, Z.; Liu, Y.H.; Yu, S.W. (2004). Effective Elastic and Plastic Properties of Interpenetrating Multiphase Composites. Applied Composite Materials, Vol.11, No.1, pp. 33-55, ISSN 0929-189X

Fukushima, K.; Tabuani, D.; Abbate, C.; Arena, M.; Rizzarelli, P. (2011). Preparation, characterization and biodegradation of biopolymer nanocomposites based on fumed silica. European Polymer Journal, Vol.47, No. 2, pp. 139-152, ISSN 0014-3057

Garoushi, S.K.; Lassila, L.V.; Vallittu, P.K. (2006). Short fiber reinforced composite: the effect of fiber length and volume fraction. Journal of Contemporary Dental Practice, Vol.7, No.5, pp. 10-7, ISSN 1526-3711 
Gasser, B. (2000). About composite materials and their use in bone surgery. Injury, Vol.31, Suppl. No. 4, pp. S48-S53, ISSN 0020-1383

Gise, A.; Curtis, R.; Hänni, M.; Suhm, N. (2006). Augmentation of implant purchase with bone cements: An in vitro study of injectability and dough distribution. Journal of Biomedical Materials Research Part B: Applied Biomaterials, Vol.77B, No.1, pp. 114-119, ISSN 1552-4973

Giannoudis, P.V.; Dinopoulos, H.; Tsiridis, E. (2005). Bone substitutes: an update. Injury, Vol.36, Suppl. No. 3, pp. S20-S27, ISSN 0020-1383

Gheduzzi, S.; Webb, J.J.C.; Miles, A.W. (2006). Mechanical characterisation of three percutaneous vertebroplasty biomaterials. Journal of Materials Science: Materials in Medicine, Vol.17, No. 5, pp. 421-426, ISSN 0957-4530

Gomez-Vega, J.M.; Saiz, E.; Tomsia, A.P.; Marshall, G.W.; Marshall, S.J. (2000). Bioactive glass coatings with hydroxyapatite and Bioglass particles on Ti-based implants. 1. Processing. Biomaterials, Vol.21, No.2, pp. 105-111, ISSN 0142-9612

Heini, P.; Berlemann, U. (2001). Bone substitutes in vertebroplasty. European Spine Journal Vol.10, Suppl, pp. S205-S213, ISSN 0940-6719

Hench, L.L.; Wilson, J. (1984). Surface-active biomaterials. Science, Vol.226, No.4675, pp. 630636, ISSN 0036-8075

Hench, L.L.; West, J.K. (1996). Biological applications of bioactive glasses. Life Chemistry Reports, Vol.13, No.3, pp. 187-241, ISSN 0278-6281

Hooper, G.J.; Rothwell, A.G.; Stringer, M.; Frampton, C. (2009). Revision following cemented and uncemented primary total hip replacement. Journal of Bone and Joint Surgery - British Volume, Vol.91B, No. 4, pp. 451-458, ISSN 0301-620X

Hulme, P.A.; Krebs, J.; Ferguson, S.J.; Berlemann, U. (2006). Vertebroplasty and Kyphoplasty: A Systematic Review of 69 Clinical Studies. Spine, Vol.31, No.17, pp. 1983-2001, ISSN 0362-2436

Itälä, A.I.; Ylänen, H.O.; Ekholm, C.; Karlsson, K.H.; Aro, H.T. (2001). Pore diameter of more than 100 micrometer is not requisite for bone ingrowth in rabbits. Journal of Biomedical Materials Research, Vol.58, No.6, pp. 679- 683, ISSN 1552-4973

Jarcho, M.; Bolen, C.H.; Thomas, M.B.; Bobick, J.; Kay, J.F.; Doremus, R.H. (1976). Hydroxylapatite synthesis and characterization in dense polycrystalline form. Journal of Materials Science, Vol.11, No.11, pp. 2027-2035, ISSN 0022-2461

Jung, H.-M.; Song, G.-A.; Lee, Y.-K.; Baek, J.-H.; Ryoo, H.-M.; Kim, G.-S.; Choung, P.-H.; Woo, K.M. (2010). Modulation of the resorption and osteoconductivity of alfacalcium sulfate by histone deacetylase inhibitors, Biomaterials, Vol.31, No. 1, pp. 2937, ISSN 0142-9612

Kappe, T.; Cakir, B.; Mattes, T.; Reichel, H.; Flören, M. (2010). Infections after bone allograft surgery: a prospective study by a hospital bone bank using frozen femoral heads from living donors. Cell Tissue Bank, Vol.11, No.3, pp. 253-259, ISSN 1389-9333

Kenny, S.M.; Buggy, M. (2003). Bone Cements and Fillers: A Review. Journal of Materials Science: Materials in Medicine, Vol.14, No.11, pp. 923-938, ISSN 0957-4530

Kim, J.; Yaszemski, M.J.; Lu, L. (2009). Three-Dimensional Porous Biodegradable Polymeric Scaffolds Fabricated with Biodegradable Hydrogel Porogens. Tissue Engineering, Part C: Methods, Vol.15, No.4, pp. 583-594, ISSN 1937-3384

Kobayashi, M.; Nakamura, T.; Tamura, J.; Kikutani, T.; Nishiguchi, S.; Mousa, W.F.; Takahashi, M.; Kokubo, T. (1999) Osteoconductivity and bone-bonding strength of high- and low-viscous bioactive bone cements. Journal of Biomedical Materials Research, Vol.48, No.3, pp. 265-276, ISSN 1552-4973 
Krenchel, H. (1963). Fibre Reinforcement (PhD Thesis). Copenhagen, Technical University of Denmark

Lewis, G. (2009). Properties of Antibiotic-Loaded Acrylic Bone Cements for Use in Cemented Arthroplasties: A State-of-the-Art Review. Journal of Biomedical Materials Research Part B: Applied Biomaterials, Vol.89B, No. 2, pp. 558-574, ISSN 1552-4973

Leeuwenburgh, S.C.G.; Jansen, J.A.; Mikos, A.G. (2007). Functionalization of oligo(poly(ethylene glycol)fumarate) hydrogels with finely dispersed calcium phosphate nanocrystals for bone-substituting purposes. Journal of Biomaterials Science, Polymer Edition, Vol.18, No.12, pp. 1547-1564. ISSN 0920-5063

Lindfors, N.; Heikkilä, J.; Koski, I.; Mattila, K.; Aho, A.J. (2009). Bioactive Glass and Autogenous Bone as Bone Graft Substitutes in Benign Bone Tumors. Journal of Biomedical Materials Research Part B: Applied Biomaterials, Vol.90B, No. 1, pp. 131-136, ISSN 1552-4973

Lotz, J.C.; Gerhart, T.N.; Hayes, W.C. (1991). Mechanical properties of metaphyseal bone in the proximal femur. Journal of Biomechanics, Vol.24, No.5, pp. 317-329, ISSN 0021-9290

Lukaszczyk, J.; Smiga-Matuszowicz, M.; Jaszcz, K.; Kaczmarek, M. (2007). Characterization of new biodegradable bone cement compositions based on functional polysuccinates and methacrylic anhydride. Journal of Biomaterials Science, Polymer Edition, Vol.18, No.7, pp. 825-842, ISSN 0920-5063

Meretoja, V.V.; Helminen, A.O.; Korventausta, J.J.; Haapa-aho, V.; Seppalä, J.V.; Närhi, T.O. (2006). Crosslinked poly(.epsilon.-caprolactone/D,L-lactide)/bioactive glass composite scaffolds for bone tissue engineering. Journal of Biomedical Materials Research, Part A, Vol.77A, No.2, pp. 261-268, ISSN 1549-3296

Middleton, J.C.; Tipton, A.J. (2000). Synthetic biodegradable polymers as orthopedic devices. Biomaterials, Vol.21, No.23, pp. 2335-2346, ISSN 0142-9612

Puska, M.; Kokkari, A.; Närhi, T.; Vallittu, P. (2003). Mechanical properties of oligomermodified acrylic bone cement. Biomaterials, Vol.24, No. 3, pp. 417-425, ISSN 0142-9612

Puska, M.; Närhi, T.; Aho, A.; Yli-Urpo, A.; Vallittu, P. (2004). Flexural properties of crosslinked and oligomer-modified glass-fibre reinforced acrylic bone cement. Journal of Materials Science: Materials in Medicine, Vol.15, No.9, pp. 1037-1043, ISSN 0957-4530

Puska, M.; Korventausta, J.; Garoushi, S.; Seppälä, J., Vallittu, P., Aho, A. (2009a). Preliminary in vitro biocompatibility of injectable calcium ceramicpolymer composite bone cement, Key Engineering Materials, Vols.396-398, Bioceramics, pp. 273-276, ISSN 1013-9826

Puska, M.; Lassila, L.; Vallittu, P.; Seppälä, J.; Matinlinna, J. (2009b). Evaluation of bisGMA/MMA resin adhesion to silica-coated and silanized titanium. Journal of Adhesion Science and Technology, Vol.23, No. 7-8, pp. 991-1006, ISSN 0169-4243

Reilly, D.T.; Burstein, A.H. (1974). The mechanical properties of cortical bone. Journal of Bone and Joint Surgery - American Volume, Vol.56A, No.5, pp. 1001-1022, ISSN 1535-1386

Rezwana, K.; Chena, Q.Z.; Blakera, J.J.; Boccaccinia, A.R. (2006). Biodegradable and bioactive porous polymer/inorganic composite scaffolds for bone tissue engineering. Biomaterials, Vol.27, No.18, pp. 3413-3431, ISSN 0142-9612

Ritchie, R.O.; Kinney, J.H.; Kruzic, J.J.; Nalla, R.K. (2006). Cortical Bone Fracture. In: Wiley Encyclopedia of Biomedical Engineering, M. Akay, (Ed.), John Wiley \& Sons, ISBN 9780-471-24967-2, Hoboken, USA

Santavirta, S.; Xu, J.W.; Hietanen, J.; Ceponis, A.; Sorsa, T.; Kontio, R.; Konttinen, Y.T. (1998). Activation of periprosthetic connective tissue in aseptic loosening of total hip replacements. Clinical Orthopaedics and Related Research, Vol.352, pp. 16-24, ISSN 0009-921X 
Santavirta, S.; Takagi, M.; Gomez-Barrena, E.; Nevalainen, J.; Lassus, J.; Salo, J.; Konttinen, Y.T. (1999). Studies of host response to orthopedic implants and biomaterials. Journal of long-term effects of medical implants, Vol.9, No.1-2, pp. 67-76, ISSN 1050-6934

Schweikl, H.; Spagnuolo, G.; Schmalz, G. (2006). Genetic and cellular toxicology of dental resin monomers. Journal of Dental Research, Vol.85, No.10, pp. 870-877, ISSN 0022-0345

Silva Nykänen, V.P.; Nykänen, A.; Puska, M.; Silva, G.; Ruokolainen J. (2011). Dual-responsive and super absorbing thermally cross-linked hydrogel based on methacrylate substituted polyphosphazene, Soft Matter, Vol.7, No.9, pp.4414-4424, ISSN 1744-683X

Shinzato, S.; Nakamura, T.; Kokubo, T.; Kitamura, Y. (2001). A new bioactive bone cement: effect of glass bead filler content on mechanical and biological properties. Journal of Biomedical Materials Research, Vol.54, No.4, pp.491-500, ISSN 1552-4973

Smit, R.S.; van der Velde, D.; Hegeman, J.H. (2008). Augmented pin fixation with Cortoss ${ }^{\circledR}$ for an unstable $\mathrm{AO}-\mathrm{A} 3$ type distal radius fracture in a patient with a manifest osteoporosis. Archives of orthopaedic and trauma surgery, Vol.128, No.9, pp. 989993, ISSN 0936-8051

Sperling, L.H. (1994). Interpenetrating Polymer Networks: An Overview. In: Interpenetrating Polymer Networks. D. Klempner, L.H. Sperling and L.A. Utracki, (Eds), 1-38, Advances in Chemistry Series 239, American Chemical Society, ISBN 0841225281 Washington, D.C., USA

Stevens, B.; Yang, Y.; Mohandas, A.; Stucker, B.; Nguyen, K.T. (2008). A review of materials, fabrication methods, and strategies used to enhance bone regeneration in engineered bone tissues. Journal of Biomedical Materials Research Part B: Applied Biomaterials, Vol.85B, No.2, pp. 573-582, ISSN 1552-4973

Tadic, D.; Epple, M. (2004). A thorough physicochemical characterisation of 14 calcium phosphate-based bone substitution materials in comparison to natural bone, Biomaterials. Vol.25, No.6, pp. 987-994, ISSN 0142-9612

Thomason, J.L. (2007). The influence of fibre length and concentration on the properties of glass fibre reinforced polypropylene: 7 . Interface strength and fibre strain in injection moulded long fibre PP at high fibre content. Composites, Part A: Applied Science and Manufacturing, Vol.38A, No.1, pp. 210-216, ISSN 1359-835X

Törmälä, P. (1992). Bioabsorbable surgical composite materials. Advanced Materials, Vol.4, No.9, pp.589-591, ISSN 0935-9648

Vallittu, P.K. (1995). Impregnation of glass fibers with poly(methyl methacrylate) using a powder-coating method. Applied Composite Materials, Vol. 2, No.1,pp.51-58, ISSN 0929-189X

Vallittu, P. (1998). Polymer-fibre prepreg, a method for the preparation thereof as well as the use of said prepreg. International Patent, No. US005846640A, pp. 10

Vieira, M.G.A.; Altenhofen da Silva, M.; Oliveira dos Santos, L.; Beppu, M.M. (2011). Natural-based plasticizers and biopolymer films: A review. European Polymer Journal, Vol.47, No.3, pp. 254-263, ISSN 0014-3057

Wang, M. (2003) Developing bioactive composite materials for tissue replacement. Biomaterials, Vol.24, No.13, pp. 2133-2151, ISSN 0142-9612

Wang, V ,; Misra, G.; Amsden, B. (2008). Immobilization of a bone and cartilage stimulating peptide to a synthetic bone graft. Journal of Materials Science: Materials in Medicine, Vol.19, No.5, pp. 2145-2155, ISSN 0957-4530

Zhang, D.; Leppäranta, O.; Munukka, E.; Ylänen, H.; Viljanen, M.K.; Eerola, E.; Hupa, M.; Hupa, L. (2010). Antibacterial effects and dissolution behavior of six bioactive glasses. Journal of Biomedical Materials Research, Part A, Vol.93A, No.2, pp. 475-483. ISSN 1549-3296 


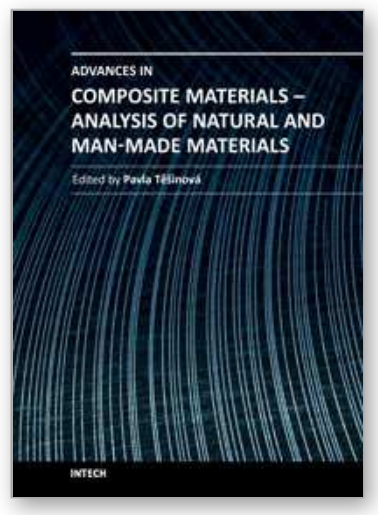

\author{
Advances in Composite Materials - Analysis of Natural and Man- \\ Made Materials \\ Edited by Dr. Pavla Tesinova
}

ISBN 978-953-307-449-8

Hard cover, 572 pages

Publisher InTech

Published online 09, September, 2011

Published in print edition September, 2011

Composites are made up of constituent materials with high engineering potential. This potential is wide as wide is the variation of materials and structure constructions when new updates are invented every day.

Technological advances in composite field are included in the equipment surrounding us daily; our lives are becoming safer, hand in hand with economical and ecological advantages. This book collects original studies concerning composite materials, their properties and testing from various points of view. Chapters are divided into groups according to their main aim. Material properties are described in innovative way either for standard components as glass, epoxy, carbon, etc. or biomaterials and natural sources materials as ramie, bone, wood, etc. Manufacturing processes are represented by moulding methods; lamination process includes monitoring during process. Innovative testing procedures are described in electrochemistry, pulse velocity, fracture toughness in macro-micro mechanical behaviour and more.

\title{
How to reference
}

In order to correctly reference this scholarly work, feel free to copy and paste the following:

Mervi Puska, Allan J. Aho and Pekka Vallittu (2011). Polymer Composites for Bone Reconstruction, Advances in Composite Materials - Analysis of Natural and Man-Made Materials, Dr. Pavla Tesinova (Ed.), ISBN: 978953-307-449-8, InTech, Available from: http://www.intechopen.com/books/advances-in-composite-materialsanalysis-of-natural-and-man-made-materials/polymer-composites-for-bone-reconstruction

\section{INTECH}

open science | open minds

\section{InTech Europe}

University Campus STeP Ri

Slavka Krautzeka 83/A

51000 Rijeka, Croatia

Phone: +385 (51) 770447

Fax: +385 (51) 686166

www.intechopen.com

\section{InTech China}

Unit 405, Office Block, Hotel Equatorial Shanghai

No.65, Yan An Road (West), Shanghai, 200040, China

中国上海市延安西路65号上海国际贵都大饭店办公楼 405 单元

Phone: +86-21-62489820

Fax: $+86-21-62489821$ 
(C) 2011 The Author(s). Licensee IntechOpen. This chapter is distributed under the terms of the Creative Commons Attribution-NonCommercialShareAlike-3.0 License, which permits use, distribution and reproduction for non-commercial purposes, provided the original is properly cited and derivative works building on this content are distributed under the same license. 